\title{
IDENTITAS SOSIAL DAN KONFORMITAS PADA ANGGOTA KOMUNITAS HIJABERS
}

\author{
Mela Rospita, Ivan Muhammad Agung \\ Universitas Islam Negeri Sultan Syarif Kasim Riau, Indonesia \\ ivan.agung@uin-suska.ac.id
}

\begin{abstract}
$A B S T R A C T$
This study aims to determine the relationship of social identity and conformity at members of Pekanbaru bijabers community. The number of subjects of this study as many as 105 members of the community hijabers Pekanbaru, and all population are taken as respondens by using strata sampling. The research data were obtained using conformity scale and social identity scale. The results of analysis using product moment correlation technique obtained $r$ value of 0.605 and $p$ significance value of $0.000(p<0.01)$. It's means that there is a significant relationship between social identity and conformity on members of Pekanbaru hijabers. This means that the higher the social identity then the conformity in Pekanbaru Hijabers members is higher. On the other hand social identity contribute 36,6\% to Pekanbaru Hijabers Community.
\end{abstract}

Keywords: Conformity; Hijabers Community; Social Identity

\begin{abstract}
ABSTRAK
Penelitian ini bertujuan untuk mengetahui hubungan identitas sosial dengan konformitas pada anggota komunitas hijabers Pekanbaru. Jumlah subjek penelitian ini sebanyak 105 orang anggota komunitas hijabers Pekanbaru, dengan menjadikan semua populasi sebagai respondenya dengan strata sampling. Data penelitian diperoleh dengan menggunakan skala konformitas dan skala identitas sosial. Hasil analisis menggunakan teknik korelasi product moment diperoleh nilai $r$ sebesar 0,605 dan nilai signifikansi $p$ sebesar $0,000(p<0,01)$. Artinya terdapat hubungan signifikan antara identitas sosial dengan konformitas pada anggota hijabers Pekanbaru. Hal tersebut berarti semakin tinggi Identitas Sosial maka semakin tinggi konformitas pada anggota Hijabers Pekanbaru. Disamping itu identitas sosial memberikan sumbangsih sebesar 36,6\% terhadap konformitas komunitas Hijabers Pekanbaru.
\end{abstract}

Kata Kunci: Identitas Sosial; Komunitas Hijabers; Konformitas

\section{PENDAHULUAN}

Jilbab merupakan salah satu simbol ketaatan bagi seorang muslimah terhadap syariat agama Islam. Jilbab dalam Islam dimaknai sebagai pakaian yang menutup seluruh tubuh dari ujung kepala sampai ke ujung kaki (Novitasari, 2014). Namun dewasa ini, jilbab bukan lagi 
merupakan salah satu simbol ketaatan bagi seorang muslimah terhadap syari'at agama Islam, tetapi telah bergeser menjadi simbol gaya hidup berbusana yang modis stylish. Kasus ini ditunjukkan dengan kemunculan komunitas-komunitas yang beratas namakan jilbab, di satu sisi komunitas dengan jilbab yang modis tetapi syar'i, sementara pada sisi yang lain muncul pula komunitas yang berjilbab tetapi masih menonjolkan bagian-bagian tubuh tertentu (Pakuna 2014).

Hijabers community adalah sekumpulan wanita yang berdandan sangat modis dan Islami, mereka terdiri dari para remaja dan ibu-ibu. Penampilan berbusana mereka sangat berbeda dengan kebanyakan wanita yang mengenakan busana muslimah, karena model pakaian yang mereka pakai sangat stylish dan modern, dari mulai jilbab, baju, sepatu, hingga tas (Pakuna 2014).

Fenomena ini bertentangan dengan perintah Allah SWT dalam berpakaian pada (QS An-Nur: 31) yang artinya secara khusus bahwa busana dan hijab bagi muslimah yaitu pakaian yang diulurkan keseluruh tubuh dari atas hingga bawah tanpa memperlihatkan sedikitpun aurat wanita. Dalam penggunaannya pun telah diatur sedemikian rupa dalam kitab suci Al-Qur'an, yang mana dalam mengenakan jilbab tidak boleh transparan, tidak memperlihatkan lekuk tubuh, sederhana dan tidak mencolok. Namun, seiring dengan perkembangan zaman, pengaruh modernisasi pun tidak dapat ditolak dan mampu mempengaruhi penggunaan jilbab bagi perempuan muslimah, khususnya mempengaruhi cara berpakaian dan penggunaan jilbab bagi wanita muslimah (Pakuna 2014).

Menurut Martin dan Hewstone (dalam Taylor, 2009), orang lebih suka menyesuaikan diri dengan perilaku kelompok bila mereka menganggap anggota kelompok itu benar dan apabila mereka ingin disukai oleh anggota kelompok. Secara psikologis, kesetiaan dan kepatuhan pada kelompok, perasaan senasib dan sepenanggungan disebut konformitas.Menurut Sears dkk (2004), mengatakan bahwa seseorang menampilkan perilaku tertentu karena setiap orang lain menampilkan perilaku tersebut disebut dengan konformitas. Santrock (2007), mengatakan bahwa konformitas terjadi apabila individu mengadopsi sikap atau perilaku orang lain karena merasa didesak orang lain (baik desakan nyata atau hanya bayangannya saja) sehingga konformitas merupakan usaha terus menerus dari individu untuk selalu selaras dengan norma-norma yang diharapkan oleh kelompok (Sarwono, 2005; Harmain, dkk, 2016). 
Sears, dkk (2004) berpendapat bahwa konformitas akan mudah terlihat serta mempunyai aspek-aspek yang khas dalam kelompok. Adapun aspek-aspek yang dimaksud adalah; 1) Aspek kekompakan.Semakin besar rasa suka dan harapan memperoleh manfaat dari kelompoknya maka semakin kompak kelompok tersebut.kekompakan diteukan oleh penyesuian diri dan perhatian terhadap kelompok, 2) aspek kesepakatan. Pendapat kelompok yang telah dibuat memiliki tekanan kuat sehingga harus loyal dan menyesuaikan pendapatnya dengan pendapat kelompoknya, dan 3) aspek ketaatan. Jika ketaatan tinggi maka konformitasnya juga tinggi. Ketaatan tersebut dapat dipengaruhi oleh tekanan karena ganjaran, ancaman, atau hukuman,dan harapan orang lain.

Konformitas anggota terhadap kelompok ditenukan banyak faktor salah satunya adalah identitas sosial anggota. Identitas sosial merupakan identitas yang melekat pada seseorang dengan identitas kelompoknya (Baron \& Byrne, 2003). Identitas sosial adalah bagian dari konsep diri yang berasal dari keanggotan dalam satu atau lebih kelompok sosial, dan dari evaluasi yang diasosiasikan dengannya (Taylor dkk., 2009).

Menurut Tajfel (dalam Ellemers, 1999) social identity theory yang terdiri dari tiga komponen, 1) cognitive component (self categorization), yaitu kesadaran kognitif akan keanggotaannya dalam kelompok, seperti self categorization, 2) evaluative component (group self esteem), yaitumerupakan nilai positif atau negatif yang dimiliki oleh individu terhadap keanggotaannya dalam kelompok, seperti group self esteem, dan 3) emotional component (affective commitment) yaitu lebih menekankan pada seberapa besar perasaan emosional yang dimiliki individu terhadap kelompoknya (affective commitment).

Indvidu yang tergabung sebagai anggota hijaber akan berusaha untuk berpikir dan berperilaku sesuai dengan norma dan aturan yang berlaku dalam kelompoknya. Anggota hijaber yang merasa menjadi bagian penting dari kelompok, menganggap kelompok cerminan dirinya akan cenderung memiliki konformitas pada kelompok. Hal ini diperkuat oleh penelitian Utami dan Silalahi (2013) yang menunjukkan hubungan yang signifikan antara identitas sosial dengan konformitas dan pada dasarnya faktor yang membentuk konformitas salah satu nya identitas sosial. Kemudian dalam penelitian Putri (2013) tentang hubungan antara identitas sosial dan konformitas dengan perilaku agresi pada suporter sepakbola persisam putra samarinda,menjelaskan bahwa perilaku agresi pada suporter Persisam Putra Samarinda yang 
rendah ditandai dengan identitas sosial yang tinggi dikarenakan adanya penanaman rasa identitas sosial yang tinggi antar sesama suporter.

Taylor dkk (2009) mengatakan social identity theory merupakan teori yang menyatakan bahwa konsep diri individu sebagian berasal dari keanggotaan dalam in-group. Semakin individu menilai kelompok dengan baik, menganggap dirinya bagian dari kelompok maka kelompok akan semakin tinggi konform dengan aturan yang ada dikelompok ini disebabkan individu telah mengkategorikan dirinya dengan kelompok. Hal ini diperkuat oleh teori Tajfel (dalam Ellemers 1999) yang mengatakan Kesadaran kognitif akan keanggotaannya dalam kelompok, seperti self categorization. Individu mengkategorisasikan dirinya dengan kelompok tertentu yang akan menentukan kecenderungan mereka untuk berperilaku sesuai dengan keanggotaan kelompoknya.Dari uraian diatas, dapat dikemukakan hipotesisnya berdasarkan kerangka teori adalah sebagai berikut : terdapat hubungan positif antara identitas sosial dengan konformitas pada anggota Komunitas Hijabers Pekanbaru. Semakin tinggi identitas sosial maka semakin tinggi konformitas pada anggota komunitas hijabers dan begitu sebaliknya.

\section{METODE}

Populasi dalam penelitian ini yaitu seluruh anggota komunitas hijabers Pekanbaru yang berjumlah 105 orang. Mengingat jumlah populasinya yang tidak banyak, maka peneliti mengambil semua populasi sebagai respondenya dengan strata sampling.

Sebagai alat ukur penelitian dilakukan dengan mengumpulkan data melalui skala identitas sosial dari Ellemers (1999). dan konformitas dari Sears dkk (2004). Kedua skala menggunakan model Liker. Skala Identitas sosial dalam penelitian ini menggunakan aspek dari Tajfel dengan modifikasi skala Ellemers (1999).Skala Identitas sosial dalam penelitian ini menggunakan tiga aspek: a) Cognitive component (self categorization),b), Evaluative component (group self esteem), dan 3) Emotional component (affective component) Jumlah aitem Identitas dalam skala ini adalah 25 aitem, 10 aitem skala baku dari Ellemers dan dimodifikasi atau ditambah oleh peneliti 15 aitem setelah tray out gugur 6 sehingga jumlah aitem untuk penelitian sebanyak 19 aitem, sementara skala konformitas penelitian ini menggunakan aspek-aspek dari teori Sears, dkk (2004). Skala Konformitas meliputi aspek:a) aspek kekompakan, b) aspek kesepakatan, dan 3) 
aspek ketaatan. Jumlah aitem skala konformitas sebanyak 36 aitem. Setelah ditray out ada 6 aitem gugur.

Penelitian ini dilakukan dengan menggunakan pendekatan kuantitatif dengan teknik korelasional, yaitu korelasi Pearson dengan bantuan program SPSS.

\section{HASIL DAN PEMBAHASAN}

Ada beberapa langkah yang dilakukan untuk hasil penelitian dan pembahasannya yaitu uji normalitas, uji linearitas dan uji hipotesis. Uji normalitas yang digunakan pada penelitian ini adalah teknik One Sample Kolmogorov-smirnov. Dengan signifikansi p >0,05, maka data akan dikatakan normal. Hasilnya dapat dilihat melalui tabel sebagai berikut. signifikan (p) sebesar 0,242 ( $>>0,05)$ untuk variabel identitas sosial artinya sebaran data identitas sosial normal, dan diketahui signifikan $(\mathrm{p})$ sebesar $0,756(\mathrm{p}>0,05)$ untuk variabel konformitas artinya sebaran data konformitas normal.Uji linearitas yang digunakan dalam penelitian ini adalah uji F, data akan dikatakan linear dengan ketentuan signifikasinya lebih kecil dari 0,05 ( $p<0,05)$.hasil pengujian linearitas pada variabel identitas sosial dengan konformitas diketahui bahwa F sebesar 30,074 dengan taraf signifikan sebesar 0,000 $(\mathrm{p}<0,01)$ dengan begitu data dikatakan linier. Berdasarkan hasil analisis product moment diperoleh koefisien korelasi r sebesar 0,605 dengan signifikansi (p) 0,000, maka $\mathrm{p} \leq 0,01$. Adapun ketentuan diterima atau ditolak sebuah hipotesis apabila signifikansi lebih kecil atau sama dengan $0,05(\mathrm{p} \leq 0,01)$, maka hipotesis penelitian tersebut diterima. Berdasarkan tabel diatas menunjukkan ada hubungan positif identitas sosial dengan konformitas pada anggota komunitas HijabersPekanbaru.Sumbangsih identitas sosial dengan konformitas adalah sebesar 36,6\%.

Penelitian ini bertujuan untuk menguji hubungan antara identitas sosial dengan konformitas pada anggota komunitas Hijabers Pekanbaru. Hasil penelitian menunjukkan terdapat hubungan positif yang signifikan antara identitas sosial dengan konformitas dengan signifikan sebesar 0,000 ( $\mathrm{p}<0,01)$ dengan nilai $\mathrm{r}$ sebesar 0,605 . Hipotesis dalam penelitian ini diterima. Hal ini menunjukkan bahwa ada hubungan positif identitas sosial dengan konformitas pada anggota komunitas Hijabers Pekanbaru, semakin tinggi identitas sosial maka semakin tinggi konformitas pada anggota komunitas Hijabers begitu pula sebaliknya semakin rendah 
identitas sosial maka semakin rendah konformitas pada anggota komunitas Hijabers Pekanbaru.

Hasil penelitian ini didukung oleh penelitian Utami (2013) yang mengatakan ketika seseorang masuk dalam sebuah komunitas, kemungkinan besar akan cenderung konform atau mengikuti peraturan dalam komunitas tersebut, bukan secara dipaksa melainkan secara sukarela karena sudah merasa menjadi bagian dari komunitas tersebut. Terjadinya konformitas pada anggota komunitas salah satunya untuk memajukan atau menjaga status kelompok mereka. Dengan upaya untuk memajukan komunitas, anggota yang tergabung akan taat dengan peraturan kelompok dan melakukan penyesuain dengan kelompok agar terlihat sama seperti anggota yang lain dengan tujuan menjaga kekompakkan. Secara tidak langsung alasan anggota komunitas Hijabers Pekanbaru konform dengan kelompok disebabkan identitas kelompok yang telah melekat pada individu.

Sumbangsih identitas sosial dengan konformitas adalah sebesar 36,6\%. Hasil tersebut menjelaskan bahwa konformitas pada anggota komunitas hijabers Pekanbaru sebesar 36,6\% dipengaruhi oleh identitas sosial. Sisanya 63,4\% ditentukan oleh faktor-faktor lain yang tidak diungkapkan dalam penelitian ini dan diduga turut berperan dalam menentukan konformitas pada anggota komunitas hijabers Pekanbaru. Menurut Baron dan Bryne (2003) faktor-faktor tersebut antara lain kohesivitas, ukuran kelompok, dan jenis norma sosial yang berlaku pada situasi tertentu.

Menjadi seperti orang lain dalam kelompok, dan melihat sesuatu dari perspektif kelompok sehingga dasar identitas sosial yaitu berada di dalam keseragaman persepsi dan tindakan antara anggota kelompok (Stets, 2000) dalam (Maukar, 2013). Hal ini didukung oleh pernyataan dalam penelitian Novitasari (2014) yang mengatakan perubahan keyakinan maupun perilaku individu terjadi apabila dirinya sungguh-sungguh percaya bahwa kelompok memiliki opini atau perilaku yang benar. Untuk memiliki pendapat yang sama dengan kelompok dan beranggapan informasi dari kelompok lebih kaya dari pada informasi milik pribadi, sehingga individu cenderung konform dalam menyamakan pendapat.

Konformitas pada anggota komunitas hijabers Pekanbaru dalam kategori sedang yang artinya didalam kelompok anggota cenderung mengikuti kebiasaan kelompok komunitas 
hijabers Pekanbaru seperti kekompakan, kesepakatan dan ketaatan dalam aturan kelompok (Sears dkk,2004).

Selain hasil penelitian utama, terdapat hasil analisa tambahan. Hasil analisis sumbangan efektif pada setiap komponen identitas sosial terhadap konformitas menunjukkan perbedaan pada setiap komponen identitas sosial tersebut. Komponen evaluatif merupakan komponen dengan persentase paling tinggi dibandingkan komponen lainnya yaitu 20\%. Tinggi nya komponen evaluatif dapat meningkatkan penilaian positif terhadap kelompok, menilai baik kelompok dan benarnya aturan kelompok. Hal ini diperkuat oleh teori Menurut Tajfel (dalam Ellemers, 1999) yang mengatakan evaluative component merupakan nilai positif atau negatif yang dimiliki oleh individu terhadap keanggotaannya dalam kelompok. Evaluative component ini menekankan pada nilai-nilai yang dimiliki individu terhadap keanggotaan kelompoknya.

\section{SIMPULAN}

Berdasarkan hasil penelitian dan pembahasan dalam penelitian ini, dapat ditarik kesimpulan bahwa terdapat hubungan yang positif antara identitas sosial dengan konformitas pada anggota komunitas Hijabers Pekanbaru dimana semakin tinggi identitas sosial maka semakin tinggi konformitas pada anggota komunitas Hijabers.Hasil penelitian ini juga menunjukkan bahwa terdapat sumbangsih Identitas Sosial dengan konformitas sebesar 36,6\%, sedangkan sisanya $63,4 \%$ ditentukan oleh faktor-faktor lain yang tidak diteliti.

\section{DAFTAR PUSTAKA}

Andriani, Mutia \& Ni'matuzahroh. (2013) Konsep Diri Dengan Konformitas pada Komunitas Hijabers. Jurnal Psikologi. Vol 01, No 01, Malang.

Arikunto, Suharsimi. (2010). Prosedur Penelitian Suatu Pendekatan Praktik. Jakarta: Rineka Cipta. Azwar, Saifuddin (2009a). Reliabilitas dan Validitas. Yogyakarta: Pustaka Pelajar. , (2012).Penyusunan Skala Psikologi. Yogyakarta: Pustaka Pelajar. , (1999). Reliabilitas dan validitas: Seri pengukuran Psikologi. Yogyakarta: Sigma Alpha.

Baron, Robert A., dan Byrne. (2003). Psikologi Sosial Jilid 1 (terjemahan Djuwita, R.). Jakarta: Erlangga. , (2003). Psikologi Sosial Jilid 2 (terjemahan Djuwita, R.). Jakarta: Erlangga. 
Erawati, Desi. (2005) Fenomena Berjilbab di Kalangan Mahasiswa (Studi Tentang Pemahaman, Motivasi dan Pola Interaksi Sosial Mahasiswi Berjilbab di Universitas Muhammadiyah Malang). Jurnal Studi Agama dan Masyarakat. Vol.2 No. 2. Kalimantan.

Ellemers, Naomi. Paulen Kortekaas \& Jaap W. Ouwerkerk. (1999). Self-Categorisation, Commitment to the Group and Group Self-Esteem as Related but Distinct Aspects of Social Identity. Eoropean Journal of Social Psychology. 29. 371-389.

Harmaini, Anastassia, D.F, Agung, I.M, \& Munthe, R.A (2016). Psikologi Kelompok: Integrasi Psikologi dan Islam. Jakarta: Rajawali Press.

Hurlock, Elizabeth .B. (2009). Psikologi Perkembangan. Jakarta: Erlangga

Interaksi Online. (2013). Pemaknaan Tren Fashion berjilbab ala Hijabers oleh Wanita Muslimah Berjilbab. (http://ejournal-s1.undip.ac.id/index.php/interaksionline/article/view/2962). Budiono, Herieningsih dan Lukmantoro. Diakses pada 29 Oktober 2015.

Pekanbaru.co. (2013). Hijab Class by Hijabers Pekanbaru. (http://www.pekanbaru.co/3839/hijab-class-hijabers-pekanbaru). Diakses pada 27 Oktober 2015.

Riaupos.co. (2012). Hijabers dan Komunitas Reptil Curi Perhatian. (http://riaupos.co/arsip13522-berita.html). Hendra Kariman. Diakses pada 27 Oktober

Karlina, A. (2014). Hubungan Konformitas Berbusana pada Anggota Komunitas Hijabers Pekanbaru dengan Kesadaran Beragama dalam Menutup Aurat. Skripsi. Pekanbaru.

Maukar, D.C. (2013) Hubungan Konformitas Remaja dan Identitas Sosial dengan Brand Loyalty pada Merek Starbuck Coffe Surabaya. Jurnal Psikologi. Vol.2. No.2

Myers, David G.(2012). Psikologi Sosial (edisi kesepulub buku 1). Jakarta: Selemba Humanika

Novitasari, Yasinta Fauziah. (2014). Makna Tradisi Jilbab Sebagai Gaya Hidup (Studi Fenomenologi Tentang Alasan Perempuan Memakai Jilbab dan Aktivitas Solo Hijabers Community). Surakarta: Skripsi. Fakultas Keguruan dan Ilmu Pendidikan Universitas Sebelas Maret.

Pakuna, Hatim Badu. (2014) Fenomena Komunitas Berjilbab: Antara Ketaatan dan Fashion. Yogyakarta. Vol 11.No. 1.

Putri, Kadek Reqno Astyka. (2013) Hubungan Antara Identitas Sosial dan Konformitas dengan Perilaku Agresi Pada Suporter Sepakbola Persisam Putra Samarinda.Jurnal Psikologi 1 (3): 241-253.

Quanesha.com. (2011). Colection of Quanesha. Hijabers Community: Trend Baru Berbusana Muslim yang Modis dan Modern. Diakses 14 Desember 2015 dari(http://quanesha.com/hijabers-community-tren-baru-berbusana-muslimyangmodis-dan-modern/).

Sarwono. W. S. (2005). Psikologi Sosial: Psikologi Kelompok dan Psikologi Terapan. Jakarta: Balai Pustaka. 
Sears, D.O., dkk. (2004). Psikologi Sosial Edisi 5 Jilid 1. Jakarta: Erlangga.

Sam's Word (2014). Hijab syar'i yang berkah atau hijab modern yang tidak mencium bau surga,pilih yang mana?. (http://samrotulfuada.blogspot.co.id/2014/12/hijab-syariyang-berkah-atau-hijab_11.html?m=1). Samrotul Fu'ada. Diakses pada 31 Maret 2016.

Santrock, J. (2007). Remaja (Adolescence) (edisi kesebelas, Jilid 2). Jakarta: Erlangga.

Sugiyono. (2013). Metedologi Penelitian Kuantitatif dan Kualitatif dan R\&D. Bandung: Alfabeta.

Syafaat,TB.Aat, Sohari Sahrani \& Muslih. (2008). Peranan Pendidikan Islam dalam Mencegah Kenakalan Remaja. Jakarta: PT Raja Grafindo Persada.

Taylor, S., Peplau, L.A., Sears, D.O. (2009). Psikologi sosial. Jakarta: Kencana.

Usman, H \& Akbar, P. S. (2008). Pengantar Statistik. Edisi ke-2. Jakarta: Bumi Aksara.

Utami, Fransisca Nurmalita Hapsari \& Betty Yuliani Silalahi. (2013) Hubungan Antara Identitas Sosial dan Konformitas pada Anggota Komunitas Virtual Kaskus Regional Depok. Jurnal Proceeding PESAT. Vol.5. Bandung. 1858-2559.

Wade, C., \& Tavris, C. (2007). Psikologi (Edisi kesembilan) jilid 1. Alih bahasa: Benedictine Widyasinta. Jakarta: Erlangga. 